\title{
BLOOD GLUCOSE TARGET ACHIEVEMENT AND ANTIDIABETES REGIMEN IN TYPE-2 DIABETIC GERIATRIC PATIENTS
}

\author{
Budi Suprapti*, Nony Vilaningtyas, Wenny Putri Nilamsari, Jusri Ichwani
}

\author{
Department of Clinical \\ Pharmacy, Faculty of \\ Pharmacy, Airlangga \\ University Surabaya, \\ Jl. Dharmawangsa dalam, \\ Surabaya 60286
}

Sub Division of Geriatric, Internal Department, dr. Soetomo General/Teaching Hospital, Surabaya, Indonesia

Submitted: $11-11-2013$ Revised: 03-02-2014

Accepted: 05-03-2014

*Corresponding author Budi Suprapti

Email :

budiprapti@yahoo.co.id

\begin{abstract}
Diabetes mellitus (DM) is a leading caused morbidity in geriatric patients. The prevalence of type-2 DM is more than $90 \%$ of DM population and increase with age, and half of those patients were geriatric. Blood glucose (BG) control is important for prevention diabetes complications, but attention must be given in geriatric patients due to the increasing susceptibility to risk of hypoglycemia. The aimed of this study was to identify BG achievement in diabetic geriatric patients and its therapeutic management. This study was done in Outpatient Geriatric Clinic, Dr. Soetomo General Hospital Surabaya Indonesia in the period of March to June, 2012. The inclusion criteria were type-2 diabetic geriatric patients with/without diabetic complication that received antidiabetic therapy and had BG data. The results from 165 patients showed that BG target achieved by $53 \%$ patients, $41 \%$ patients not achieved the target, while $6 \%$ patients in risk of hypoglycemia. Management therapy for patients with achieved BG target was done by (1) continued therapy as before, (2) increasing dosage regimen for patients with BG already in the target but still within the upper limit target or decrease dosage regimen for patients with $B G$ in lower limit target to avoid hypoglycemia, (3) change type of medication for patients who experienced side effects. Meanwhile, from all patients that failed to achieve BG target there were some patients received additional medications and regimen changes, but the rest of those didn't receive any additional medication or regimen changes, which were many of them eventually became one of the drug-related problems in this patient group. In conclusion, there were still quite large number patients that did not achieve BG target, therapy management changes were made based on BG profile and there were drug related problems related to dosage regimen that needs pharmaceutical care intervention
\end{abstract}

Key words: antidiabetic, regimen, blood glucose achievement, geriatric

\section{INTRODUCTION}

Elderly patients usually present with one or more degenerative diseases and about $60 \%$ of the population had a history of at least one chronic disease including diabetes (Naughton and Feely, 2006). Diabetes is a common chronic disease with the prevalence increases with age (Fauci et al., 2008) and one of major cause of disability in the elderly (Triplitt $e t$ al., 2008). The prevalence of type 2 diabetes in the elderly is likely to increase, generally $90 \%$ of adult patients with diabetes, diagnosed as type 2 diabetes and $50 \%$ of that were older than 60 years (Gustaviani, 2006). Because of carbohydrate metabolism disorder, elderly is more prone to suffer from diabetes (Chun, 2003).

Blood sugar control in diabetes mellitus is essential to prevent a variety of chronic complications, both microvascular, macrovascular and neuropathic. However, special precaution should be given because there are a lot of changes in pharmacokinetics and pharmacodynamics that can bring the patient to a greater risk of hypoglycemia (Triplitt et al., 2008). Study Action to Control Cardiovascular Risk in Diabetes (ACCORD) conducted a study in a population with an average age of 62 years with diabetes since 10 years, comparing the strategy of intensive 
glycemic (HbA1c $<6.0 \%$ ) with a standard (target HbA1c of $7.0 \%$ ). Results showed the risk of death was higher in the intensive group and likely caused by hypoglycemia (257 vs. 203 events deceased) (Gerstein et al., 2008). This study was conducted to identify the blood glucose achievement in geriatric patients with diabetes mellitus and therapeutic management.

\section{MATERIAL AND METHODS}

This is a prospective cross-sectional study, conducted at outpatient clinic Dr. Soetomo Hospital Surabaya Indonesia from March to June 2012, using secondary data. The inclusion criteria were all geriatric patients with type-2 diabetic, with/without diabetic complication, had received antidiabetic therapy and complete BG data. Sampling was done by simple random sampling technique to obtain 165 samples of research. The methodology of this study was approved by Ethic Committee Dr. Soetomo Teaching Hospital, Surabaya Indonesia

\section{RESULT AND DISCUSSION}

From 165 patients enrolled, there were higher female patients than males (64\% vs. $36 \%$ ) (Table I). National Commission on the Elderly in 2010 reported that population of older women in Indonesia was almost $60 \%$, higher than men. The patients were grouped into middle age patient (60-65), old age (66-75), very old age (76-85) and oldest old age (> 85) (Shephard, 1998) (Table I).

Table I. Characteristic of type $2 \mathrm{DM}$ patients in geriatric outpatients Dr. Soetomo Hospital

\begin{tabular}{|c|c|c|}
\hline No & Characteristic & $\begin{array}{c}\text { Number of } \\
\text { Patients }(\%)\end{array}$ \\
\hline \multirow[t]{4}{*}{1.} & Gender: & \\
\hline & Female & $106(64)$ \\
\hline & Male & $59(36)$ \\
\hline & Total & 165(100) \\
\hline \multirow[t]{6}{*}{2.} & Age (Year) : & \\
\hline & $60-65$ & $32(19)$ \\
\hline & $66-75$ & $87(53)$ \\
\hline & $76-85$ & $44(27)$ \\
\hline & $>85$ & 1(1) \\
\hline & Total & 165(100) \\
\hline
\end{tabular}

Elderly is susceptible to chronic complications of diabetes that can increase morbidity and mortality (Kurniawan, 2010). A patient may experience more than one complication or comorbid. Previous research result showed most complications were cardiovascular disease (42\%) and stroke (18\%). Cardiovascular disease and stroke are the macrovascular complications caused by advanced glycation end (AGEs) products (Funk, 2010). In addition, most comorbid experienced by patients was hypertensive as much as $86 \%$.

Treatment of type $2 \mathrm{DM}$ is started with a non-pharmacological therapy (healthy lifestyle) or OAD monotherapy. If it fails to decrease $\mathrm{BG}$, then a combination of 2 to 3 oral antidiabetics (OAD) are given. If the target is not achieved with the combination then the combination of basal insulin and OAD is recommended. When the latest combination fails to control glucose levels, then the $\mathrm{OAD}$ is discontinued and insulin combination therapy is started. Therapy is stated to fail when $B G$ target cannot be achieved in 2-3 months at each level (PERKENI, 2011).

Result showed that from totally antidiabetes drug used, $86 \%$ were OADs and $14 \%$ were insulin, administered as single or in combination. The use of insulin was lower than OAD because insulin therapy requires special considerations including the ability to use insulin injections, recognizing and managing the condition of hypoglycemia, as well as the visual function, cognitive, availability of caregiver and patient financial capability (Neumiller and Setter, 2009).

Table II demonstrates that most drugs used were sulfonylureas, as much as $80 \%$ of the patients. The sulfonylureas were effective in achieving blood glucose target in elderly patients (Abbatecola and Paolisso, 2009). However, patients should pay special caution because hypoglycemia risk increases in old age.

Glimepirid is a long-acting sulfonylurea with half life of $9 \mathrm{~h}$, duration of action $24 \mathrm{~h}$ and has an active metabolite (Wickersham, 2009, Sweetman, 2009). Glimepirid is eliminated by liver and kidney by 60\% (Lee, 2009, Sweetman, 2009). Kidney function tends to decline in old age leading to decrease of drug excretion (Dipiro et al., 2008). 
Table II Types of antidiabetic used in geriatric outpatients Dr. Soetomo Hospital

\begin{tabular}{llrc}
\hline Class & \multicolumn{1}{c}{ Name } & Number of Patients (\%) & Total Patients (\%) \\
\hline Sulfonylurea & Glimepirid & $70(42.42)$ & \\
& Gliklazid & $46(27.88)$ & $132(80.00)$ \\
& Glikuidon & $16(9.70)$ & $63(38.18)$ \\
Biguanid & Metformin & $63(38.18)$ & $1(0.61)$ \\
Tiazolidindion & Pioglitazon & $1(0.61)$ & $70(42.42)$ \\
Inhibitor & Akarbose & $70(42.42)$ & $11(6.67)$ \\
$\begin{array}{l}\alpha \text {-glukosidase } \\
\text { Rapid acting }\end{array}$ & Aspart & $9(5.45)$ & $19(11.52)$ \\
insulin & Glulisine & $2(1.21)$ & $13(7.88)$ \\
Long acting & Glargine & $9(5.45)$ & \\
insulin & Detemir & $10(6.06)$ & \\
Premixed & $70 \%$ aspart protamin, & $13(7.88)$ & \\
insulin & $30 \%$ aspart & & \\
\hline
\end{tabular}

\section{Antidiabetic Combination}

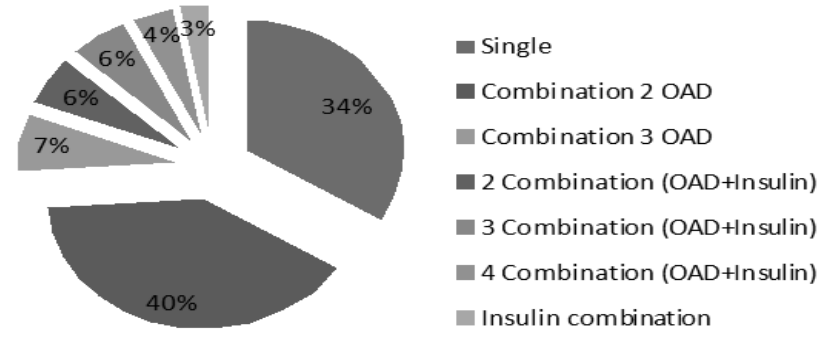

Figure 1. Percent of single and combination of antidiabetes drug in geriatric outpatients Dr. Soetomo Hospital

To avoid the risk of hypoglycemia, short-acting sulfonylurea is preferred because of less hypoglycemia risk than that of long-acting (Lee, 2009). However, glimepirid is still used because glimepirid can be administered once a day that can improve patient compliance (Neumiller and Setter, 2009). Short acting sulfonylureas are gliclazide and gliquidon because they have short duration of action and without active metabolites. Glikuidon and gliclazide can be used in patients with renal disorder as they excreted more through the liver (Lee, 2009). The use of single and combination therapy can be seen in Figure 1.

The dose and regimen of oral anti antidiabetics can be seen in table III, whereas for insulin is listed in table IV. Glimepirid dose was 0.5 to $4 \mathrm{mg}$ and used 1-2x per day (Table
IV). Glimepirid maximum dose is $6 \mathrm{mg}$ (PERKENI, 2011). Gliclazide dose was 30$240 \mathrm{mg}$ and the regimen were $1 \mathrm{x} 1,2 \mathrm{x} 1,2-1-0$ while the maximum dose is $320 \mathrm{mg}$ with frequency use 1-2x a day (PERKENI, 2011). Regimen 2-1-0 was appropriate if the total dose needed is more than $160 \mathrm{mg} /$ day (Sweetman, 2009). Glikuidon dose given to the patients was $15-60 \mathrm{mg}$ divided in 1-2x a day and 30mg with regimen 2-1-0, 1-1/2-0. Maximum dose of glikuidon is $120 \mathrm{mg}$ which divided in $2-3 \mathrm{x}$ daily (Sweetman, 2009). In order to achieve optimal control BG with minimal side effects, the dose was adjusted individually.

In this study, acarbose dose used were 50 and $100 \mathrm{mg}$ with frequency of usage was $1-3 \mathrm{x}$ per day (Table III) while, maximum dose recommended is $300 \mathrm{mg}$ divided in $1-3 x$ per day 
Budi Suprapti

Table III. Dose and regimen of oral antidiabetes in geriatric outpatients Dr. Soetomo Hospital

\begin{tabular}{|c|c|c|}
\hline Drug & Dose & Regimen \\
\hline Glimepirid & $1-4 m g$ & $\begin{array}{l}1 \times 1 \text { morning } \\
1 \times 1 / 2 \\
2 \times 1\end{array}$ \\
\hline Gliklazid & $30-80 \mathrm{mg}$ & $\begin{array}{l}1 \times 1 \\
2 \times 1 \text { or } 2-1-0\end{array}$ \\
\hline Glikuidon & $30 \mathrm{mg}$ & $\begin{array}{l}1 \times 1 \text { or } 1 / 2 \\
2 \times 1 \text { or } 2-1-0 \text { atau } 1-1 / 2-0\end{array}$ \\
\hline $\begin{array}{l}\text { Metformin } \\
\text { Pioglitazon }\end{array}$ & $\begin{array}{l}500 \mathrm{mg} \\
15 \mathrm{mg}\end{array}$ & $\begin{array}{l}1-3 \times 1 \text { evening } \\
1 \times 1\end{array}$ \\
\hline
\end{tabular}

Note : -Every patient can received more than 1 OAD.

Table IV. Dose and regimen of subcutan insulin in geriatric outpatients Dr. Soetomo Hospital

\begin{tabular}{lll}
\hline \multicolumn{1}{c}{ Drug } & \multicolumn{1}{c}{ Dose } & Regimen \\
\hline Aspart & $6-14 \mathrm{U}$ & $3 \mathrm{x}$ \\
Glulisine & $12 \mathrm{U}$ & $3 \mathrm{x}$ \\
Glargine & $10-20 \mathrm{U}$ & $1 \mathrm{x}$ morning or evening \\
Detemir & $8-20 \mathrm{U}$ & $1 \mathrm{x}$ morning or evening \\
70 Aspart Protamin/ 30 Aspart & $12 \mathrm{U}-20 \mathrm{U}$ & $12-0-12 \mathrm{U}$ \\
& $16-0-14 \mathrm{U}$ & $16-0-14 \mathrm{U}$ \\
& $14-0-16 \mathrm{U}$ & $14-0-16 \mathrm{U}$ \\
& $24-0-10 \mathrm{U}$ & $24-0-10 \mathrm{U}$ \\
& $24-0-20 \mathrm{U}$ & $24-0-20 \mathrm{U}$ \\
\hline
\end{tabular}

(Sweetman, 2009). Acarbose is not recommended in patients with renal failure with creatinine clearance $\leq 24 \mathrm{~mL} / \mathrm{min}$ (Neumiller and Setter, 2009). Metformin dose used in this study was $500 \mathrm{mg}$ with a frequency of $1-3 \mathrm{x}$ per day. Metformin does not cause side effects hypoglycemia (Neumiller and Setter, 2009). Metformin can lose weight so that it can be used in patients who are obese (McEvoy, 2008).

Thiazolidinediones used in this study was pioglitazon (1 patient) (Table III). Patients who have congestive heart failure stage III and IV should be aware when using thiazolidinediones, because it can cause edema (Neumiller and Setter, 2009). Pioglitazone has a lower risk of myocardial infarction compared to rosiglitazone (Neumiller and Setter, 2009). In addition, pioglitazone may improve endothelial function, increase levels of HDL (Triplitt et al., 2008). The doseose used in this study was $15 \mathrm{mg}$ once daily with the maximum dose is 45mg/day (Wickersham, 2009).
Geriatric patients require insulin in hyperglycemic conditions which are difficult to control and condition which are contraindicated with OAD (Tanwani, 2011). In this study, rapid-acting insulin was used by $6.67 \%$ patients, while long-acting insulin was used by $11.52 \%$ patients whereas premixed insulin (70\% aspart protamine, 30\% aspart) was used by $7.88 \%$ patients (Table II). Elderly patients with irregular eating schedule can benefit from the use of rapid-acting insulin (Tanwani, 2011). Long-acting insulin has a long duration of action and used once a day making patient compliant to increase. In addition, insulin glargine reduced the incidence of nocturnal hypoglycaemia hence appropriate for the elderly who are at greater risk of hypoglycemia (Neumiller and Setter, 2009). The advantage of premixed insulin is more flexible because it lowers the frequency of intensive insulin injection (Tanwani, 2011). 
Table V. Blood glucose achievement of tipe 2 DM patients in geriatric outpatients Dr. Soetomo Hospital Surabaya

\begin{tabular}{|c|c|c|c|c|}
\hline No. & $\begin{array}{l}\text { Blood Glucose } \\
\text { Achievement }\end{array}$ & $\begin{array}{c}\text { Management } \\
\text { Therapy }\end{array}$ & $\begin{array}{l}\text { Number of } \\
\text { patient }(\%)\end{array}$ & Reason \\
\hline \multirow[t]{5}{*}{1.} & $\begin{array}{l}\text { Achieved Target } \\
\text { (FPG 100-125 }\end{array}$ & No Change & $65(39.4)$ & Target has been achieved \\
\hline & $\begin{array}{l}\mathrm{mg} / \mathrm{dl}, 2 \mathrm{hPP} 145- \\
180 \mathrm{mg} / \mathrm{dl}, \mathrm{CPG} \\
\leq 180 \mathrm{mg} / \mathrm{dl})\end{array}$ & $\begin{array}{l}\text { Reduce Regimen } \\
\text { / Reduce the } \\
\text { number of drug }\end{array}$ & $7(4.2)$ & $\begin{array}{l}\text { Blood Glucose Level was } \\
\text { close to the lower limit }\end{array}$ \\
\hline & & $\begin{array}{l}\text { Increase Regimen/ } \\
\text { Add other drugs }\end{array}$ & $11(6.7)$ & $\begin{array}{l}\text { Blood Glucose Level was } \\
\text { close to the upper limit }\end{array}$ \\
\hline & & Change Drug & $5(3.0)$ & $\begin{array}{l}\text { Patients suffered from adverse } \\
\text { drug reactions }\end{array}$ \\
\hline & & Total & $88(53.3)$ & \\
\hline \multirow[t]{5}{*}{2.} & $\begin{array}{l}\text { Not achieved } \\
(\mathrm{FPG}>125 \\
\mathrm{mg} / \mathrm{dl}, \\
\mathrm{CPG} \& 2 \mathrm{hPP}>\end{array}$ & No Change & $35(21.2)$ & $\begin{array}{l}\text { - } 20,6 \% \text { were close to target } \\
\text { - 2,4\% needed additional drug } \\
\text { because blood glucose levels } \\
\text { were far from the target }\end{array}$ \\
\hline & & $\begin{array}{l}\text { Increase } \\
\text { Regimen/Add } \\
\text { other drugs }\end{array}$ & $18(10.9)$ & $\begin{array}{l}\text { In order to achieve blood } \\
\text { glucose target }\end{array}$ \\
\hline & & $\begin{array}{l}\text { Reduce Regimen } \\
\text { /Reduce the } \\
\text { number of drug } \\
\text { at }\end{array}$ & $7(4.2)$ & $\begin{array}{l}\text { Patients suffered from adverse } \\
\text { drug reactions }\end{array}$ \\
\hline & & Change Drug & $7(4.2)$ & $\begin{array}{l}\text { The previous regimen failed } \\
\text { to achieve target, so the drug } \\
\text { was changed }\end{array}$ \\
\hline & & Total & 67 (40.6) & \\
\hline 3. & $\begin{array}{l}\text { Hypoglycemia } \\
\text { Risk } \\
(\leq 110 \mathrm{mg} / \mathrm{dl})\end{array}$ & - & $10(6.1)$ & $\begin{array}{l}1,8 \% \text { patients had blood } \\
\text { glucose levels very low. } \\
\text { Therefore, the drug were } \\
\text { switched to another drug that } \\
\text { has lower potency. }\end{array}$ \\
\hline
\end{tabular}

Decision to give rapid-acting insulin is based on the $2 \mathrm{~h}$ postprandial glucose levels whereas a long-acting insulin levels is based on fasting plasma glucose/casual plasma glucose. In this study, insulin dosage given to patients varies (Table IV) and adjusted based on individual response, which was assessed from the glucose levels. Regimen instructed to patients was appropriate include rapid acting $3 \mathrm{x}$ daily, long acting insulin $1 \mathrm{x}$ daily at night or in the morning while the premixed insulin used 1-2x a day in the morning and evening (Table IV).

The patients were routinely checked the BG levels (CPG, FPG and 2hPP) every month. For patients older than 60 years, the target achievement can be higher than adults with Type 2 DM. Target achievement of FPG is $100-125 \mathrm{mg} / \mathrm{dL}, \quad 2 \mathrm{hPP}$ is $145-180 \mathrm{mg} / \mathrm{dL}$ (PERKENI), 2011) and CPG is less than $180 \mathrm{mg} / \mathrm{dL}$ (ADA, 2012). The risk of hypoglycemia may increase in patients with 
very tight control of glucose levels that is $\leq$ $110 \mathrm{mg} / \mathrm{dL}$ (Wiener et al., 2008).

In this study as much as $53.3 \%$ patients achieved blood glucose levels, $40.6 \%$ failed to achieve and 6.1\% suffered from hypoglicemia. Management for the patients is depend on BG level and directed individually. From total patients who achieved target, 39.4\% patients had no change of therapy, $4.2 \%$ patients was reduced regimen or reduced drug because glucose levels were close to lower limit and 9.7\% patients were increased regimen or given additional drug or changed to another drug that more potent because glucose levels were close to upper limit (Table V).

From total patients who failed to achieve target $21.2 \%$ patients had no change of therapy. From those patients, $20.6 \%$ were close to target and $2.4 \%$ patients were still far from target, therefore it was drug related problem. As much as $10.9 \%$ failed to achieve target received dose escalation or additional drug. Reduced regimen or reduced numbers of drugs were done in $4.2 \%$ patients who were sometimes experienced from hypoglycemia/adverse drug reaction. Meanwhile the rest $4.2 \%$ patients had changed the drugs therapy. Some patients $(6.1 \%)$ who at risk of hypoglycemia (BG $<110 \mathrm{mgdL}$, for geriatric) were changed to another drug that has lower potency to decrease risk of hypoglycemia (Table V).

\section{CONCLUSION}

The number of diabetic geriatric patients who did not achieve the target BG is still quite large, therapy management changes made based on BG profile individually and there are drug related problems in dosage regimen that needs pharmaceutical care intervention.

\section{ACKNOWLEDGMENT}

We are grateful to the Department Clinical Pharmacy, Faculty of Pharmacy, Airlangga University Surabaya and Sub Division of Geriatric, Internal Department, dr. Soetomo General/Teaching Hospital, Surabaya for support.

\section{REFERENCES}

Abbatecola, AM. and Paolisso, G. 2009. Diabetes Care Targets in Older Persons. Diabetes Res Clin Pract, 86S: S35-S40.
Chun, AK. 2003. Diabetes Mellitus. In : Soriano, R.P (Ed.), Fundamentals of Geriatric Medicine A Case Based Approach. New York: Springer, pp. 437-449.

Fauci, AS., Braunwald, E., Kasper, DL., Hauser, SL., Longo, DL., et al., 2008. Harrison's Principles of Internal Medicine. 17th Ed. New York: McGraw Hill.

Funk, JL. 2010. Disorder of The Endocrine Pancreas. In: Mc.Phee S.J (Ed.), Pathophysiology of Disease An Introduction to Clinical Medicine. $6^{\text {th }}$ Ed. New York: Mc Graw Hill.

Gustaviani, R. 2006. Diagnosis dan Klasifikasi Diabetes Melitus. In : Sudoyo, A.W. \& Setiyohadi, B (Eds.), Buku Ajar Ilmu Penyakit Dalam Edisi IV Jilid III. Jakarta: Balai Penerbit FKUI, pp. 1879-1885.

Gerstein, HC., Miller, ME. and Byington, R.P. 2008. For The Action To Control Cardiovascular Risk In Diabetes Study Group. Effects Of Intensive Glucose Lowering In Type 2 Diabetes. $N$ Engl J Med. 358:2545-2559.

Kurniawan, I. 2010. Diabetes Melitus Tipe 2 pada Usia Lanjut. Majalah Kedokteran Indonesia. $60: 12$.

Lee, FTH. 2009. Advances in Diabetes Therapy in The Elderly. Journal of Pharmacy Practice and Research (JPPR), 39(1) : 63-67.

McEvoy, GK. 2008. AHFS Drug Information. Bethesda : American Society of Health System Pharmacist.

Neumiller, JJ. and Setter, SM. 2009. Pharmacologic Management of The Older Patient. Am.J.Geriatr.Pharmacother, $7(6)$ : 324-342.

PERKENI (Pengurus Besar Perkumpulan Endokrinologi Indonesia). 2011. Konsensus Pengelolaan dan Pencegaban Diabetes Mellitus Tipe 2 Di Indonesia. Pengurus Besar Perkumpulan Endokrinologi Indonesia.

Sweetman, SC. 2009. Martindale: The Complete Drug Reference. 36 th $E d$. London: Pharmaceutical Press.

Shephard, RJ. 1998. Aging and Exercise. In: Fahey, T. D. (Ed.), Encyclopedia of Sports Medicine and Science, Date of published March, 7 1998, access from Society for Sport Science: http://sportsci.org. 
Tanwani, LK. 2011. Insulin Therapy in the Elderly Patient With Diabetes. Am.J.Geriatr Pharmacother. 9(1): 24-33.

Triplitt CL, Reasner CA., Isley NL, 2008, Diabetes Mellitus, in Dipiro JT et al, Pharmacotherapy. A Pathophysiology Approach, $7^{\text {th }}$ ed., Mc Graw Hill Medical, New York, 1205-1241.
Wickersham, RM. 2009. Drug Facts and Comparison Pocket Version. California : Wolters Kluwer Health, pp. 176-210.

Wiener, RS., Wiener, DC., and Larson, RJ. 2008. Benefits and Risks of Tight Glucose Control in Critically Ill Adults. $J A M A, 300(8)$ : 933-944. 